\title{
The Socio-Political Aspect in Ibsen`s Plays
}

\author{
Dr. Rregjina Gokaj \\ Faculty of Education, University "Aleksandër Moisiu" Durrës, Albania \\ rregjinagokaj@gmail.com \\ Dr. Olimbi Velaj \\ Faculty of Education, University "Aleksandër Moisiu" Durrës, Albania \\ olimbiolimbi@gmail.com
}

\section{Doi:10.5901/mjss.2013.v4n11p676}

\begin{abstract}
When Ibsen was first introduced to the audience, few might have thought that a new wit is coming up in the world theatre. His plays soon started to touch sharp social topics stigmatizing the political values of the leading class. This article analyzes the aspects that Ibsen's plays more often offered to the reader and to the audience: the socio-political ones. The plays taken into consideration are the most notable of the playwright, A Doll's House, Ghosts, Pillars of Society. The socio-political aspect in these plays is clearer and marks the starting point of a new epoch in which the writers began bringing to light real problems to the real world. The reader or the audience becomes a witness of the moral intrigue development; of the farce identity; where the high building of lies slowly begins to fall apart like a card-house. This article brings to comparison the main characters of these plays, the Ladies, respectively Mrs. Helmer, Mrs. Alving and Mrs. Bernick, which might have not been considered as the protagonists, but surely their position in the plays has been crucial in the tide of the events and in our analysis of the social and political aspect of Ibsen's plays.
\end{abstract}

Keywords: play, socio-political aspect, moral clash, protagonist etc.

\section{Ibsen and His Socio-Political Plays}

At the beginnings of Ibsen's career, little was known about him, about his views and ideology. The less was known about the plays which covered sharp social topics stigmatizing the political values of the leading class. Being presented by Edmund Gosse and Bernard Shaw in the British audience, Ibsen soon became famous not only in Britain, but also in Europe for his style of writing. Later he was widely recognized as the greatest contemporary writer of the continent and many critics began to study and write about his genius and originality. One of the criticisms that took place and embraced an extensive space of discussions within the writers and critics circles of the time, was the socio-political aspect of his works. One of his political comedies The League of Youth, for example, written in 1869, does not have much affinity with his social dramas written later, that is because his previous works are depicted by an ubiquitous change in form and intonation.

If we analyze his subsequent seven or eight plays, there is an inherent series between them identified in the different treatment of life at that period in Norway. They are inspired by the same modern spirit, all of them bare from the idealistic, lyrical or conventional facade. Surely, this article will focus on three or four of them, but mainly being aware of the fact that Ibsen does not belong to that wide group of writers that can satisfy any taste of any reader, because of the seriousness of his work makes it somewhat a compelling author. With his play in ten acts The Emperor and The Galilean in 1873, he passed smoothly from verse to prose, thus marking the rejection of the verse as the strongest means of expression. ${ }^{1}$ His experience of observing politically and philosophically the society conditions appears dissolved in the

\footnotetext{
1 In a letter to Edmund Gosse, Ibsen writes: "there is some point I have to discuss with you. You think my new drama should be written in verses, and if so, it would have some advantages. I just have to merely contradict you here, because the part, as you will see yourself, is developed in the most realistic possible way. The illusion l'd like to transmit is truth itself, l'd like to give in the eyes of the reader the impression to what he is reading is just happening in front of his eyes. If I would need to make use of the verse, I would exterminate it, realising in this way my own purpose and the target put to myself. The diversity of the common and unimportant characters which have been deliberately included in the plays would be erased and mixed up if I would have permitted them to talk to each other according to
} 
form of an in-depth view of history and life, which undergo a profound revolution, thorough and comprehensive at the same time. In this period of his literary career, it seems like he arises equipped with a new dimension on life; it seems like awakes and thinks that the world around him is living the Last Act of a prolonged drama, where all actors except politics, morality and literature, feed the man with the last remaining crumbs on the revolution table of the eighteenth century; where FREEDOM, QUALITY, FRATERNITY were the banners of the time, but in fact all of them meant exactly the opposite. Politicians could not understand the real revolution would come from the revolt of the human soul, where his country was the curse of the individual self. ${ }^{2}$ The lens of hope for an immediate future helped lbsen notice the horizon of that moral deadly disease symptoms, which, as it seemed to him, influenced Europe to fall very quickly to social death. In his with socio-political dramas he attacked the hypocrisy of society and the brutality of personal pride, negative traits of the time where the society was sinking deeper and deeper. Under these impressions he began writing plays which followed to twelve years of subsequent literary creativity. (1877-1889)

His socio-political views are clear in dramas such as Pillars of Society, A Doll's House, Ghosts, An Enemy of the People, Wild Duck, Rosmersholm and The Lady from the Sea. Moreover, this drama has followed a political comedy The League of the Youth, which also represented the social and political aspects of life in a small town in Norway. Thus, Pillars of Society ${ }^{3}$ increased public interest towards the author, even though in its initial stage did not resembled as original as it might look in the decades to come. The strength of purpose, the depth of psychological observation and freedom from passion are some elements of expression at high artistic levels that characterize this play. Social disease that is treated in this play is the hypocritical respect act, treated as a prudent and false calmness. It keeps the language so carefully in close social circles and wraps around itself the consciousness of guilt, dress after dress, insisting between false ownership, false indignation and discreet hypocrisy. The hero of the play is the Consul Bernick, who owns the earliest and most profitable industry in the city, the shipbuilding - the main industry or the pillar on which the community of that area is sustained. The Consul, not only acts as a support to trade and finance of that small locality, but gives evaluable marks to his social personality using his moral assessment. Although characters such as Dina Dorf or Lady Bernick's brother, Johan Tonneson, stain the Consul's golden, radiant disk of morality and personality with their vicissitudes, these are left unmentioned at the beginning of the drama. Such a composition technique is used in order to pick all public sympathy towards Bernick at first, so that his fall at the end would be more striking; also the public reaction to the disclosure of the truth would be deeper and the revolt more prominent and high.

Bernick's boasting about high morality level is so ubiquitous since the first act, that the play takes some nuances of a comedy. So much is he estimated that it is difficult to find even the smallest criticism towards his authority, which may harm this strong pillar of the social building. But the wit Ibsen does not let us wander too far such a bluster, for, as soon as the second act is browsed, we learn that the Berenick's reputation is based entirely on a false structure, which makes us even more curious about his ambiguous character. At first it seemed like Bernick was that kind of person who fed himself with the complacency of the fool, but in fact his portrait was a deep draft of cunning hypocrisy, a brilliant masterpiece of deliberate boastful force. The reader becomes a witness of the moral intrigue development; where the

rythmic movements. We do not live in Shakespearean epoch anymore; also debates have risen among the sculptors if their works of arts should be tinted with vivid colours or not. Too much pros and cons can be said to these practices. As for me, I would not prefer Venus tinted, but l'd rather see a negro's head sculpted in a black marble rather than white. In the whole, my impression is that the literary form must be related to the sum of the perfection spread during its presentation. My new play is not really a tragedy in the old connatation of this word, but I have made my efforts to depict there some human beings, whom I could not let speak the 'language of Gods'. Egan, Michael. Henrik Ibsen. The Critical Heritage.London \& N. York. 1972. pg. 78

${ }^{2}$ According to Ibsen, since 1870, in his political convictions the most predominant view was that the State was the natural enemy of the individual. Away from his country, he used to live in Dresden, Germany, where he enjoyed the freedom of his own individual under a small and unimportant government. As soon as this government began to empower in 1875, he left for Mynich, still hoping that only there he could taste the real free breath of spiritual life, better than in the previous place. (Author's concerns in the letter to Edmund Gosse. April, 1875) Egan, Michael. Henrik Ibsen. The Critical Heritage.London \& N. York. 1972. pg. 80

${ }_{3}^{3}$ Pillars of Society was written in 1877. Ibsen made a crucial theme of the play the corruption and the disguisement of the rich class, which is represented as a selfish and a gluttonous one. Bernick, the Consul, is the epicentre of the play, a very rich businessman and the owner of a small fleet in a coastal city in Norway. Despite the dubious way he got rich, he is considered a successful and respectable person in the city. He got married to Betty, and the couple has a son named Olaf. Bernick held a difficult position in society, not only from the fact of being a Consul, but also because of the fact that his reputation was somehow dependent from the community, which regarded him as one of the pillars of society, as a high morality and infallible individual, as the model citizen to be followed at, as a person you can hardly find something to reprimand for. When his relatives revealed that he was not at least one of these suggested to be, eventually he could not wait for the community to discover, but went on an open public speech to admit all his errors and fallacies. He did so just in time, when all the members of the community had come to celebrate the prominence of his moral dignity as one of the pillars of society. 
high building of lies slowly begins to fall apart like a card-house. The episode of Dina Dorf's mother shows that it is Bernick himself the actor of the second dirty act and not Johan, who sacrificed himself to save the image of the Consul from being spotted. The theft story is a farce so carefully devised by Bernick. It tends to come to the surface with Johan's return from America. In fact, only the reader and the audience gets familiar with these truths, while the crowd is still ignorant of the intrigues. In its ignorance, it continues to glorify Bernick up to the end of the play:

\begin{abstract}
Rerlun: Very Honorable Consul! .... the cry of our hearts impelled us to come to you and express our feelings of the deepest respect. It is not the first time that this happens, but it is the first time that happens in these grandious dimensions. Progressively we bring you our thanks to those of sound moral foundations upon which you build our lives. Today we come mainly to honor our visionary, tireless, disinterested, selfless fellow, who has taken the initiative to do a job, which in the unanimous opinion of the all competent people here, will give a powerful impetus boom and progress to our city.

Voices from the crowd: Well done! Well done!

Rerlun: Mr. Consul! There are many years You serve as a shining example for our city. I'm talking here not about your exemplary family life, for your spotless moral attitude ... No. .... Ships, equipped at their best, sail out of your dockyards taking our Norwegian flag to the most distant seas and shores. The big and happy family of workers sees in you its father. You have given rise to the happiness of hundreds of families by creating new branches of industry. In other words, you are themain pillar of our society, in the highest sense of the word.

But the honour that the crowd offers to Bernick exactly in front of his house is just a cynical approachwhere the author deliberately puts the audience, which, in turn, knows best the truth. It is this crowd that now awaits the response of his 'high morals' as a payback for all the scams made. Eventually, Bernick's reaction is appropriate and much awaited: detailed breakdown of his guilt in front of everyone, in front of the eyes of his accomplices, a sudden reaction, which seems a strange and incredible behavior for his fellows. Now everything becomes clear and the last lesson Bernick himself takes out of the situation, is:

Bernick: And we were left alone. My name is not written anymore on firing letters, in the windowpanes there have been obliterated ...

Lona: Would you like to make them burn again?

Bernick: For nothing in the world. Well, where have I been! If you only knew, you would tremble! It seems like I came around after a severe poisoning. But I feel ... that I can still rejuvenate and recuperate myself. Oh, come, gather around me! Approach Betty! Come here! But we ... a long day of hard work is waiting for us, especially me. But, no problem, let it come, you just get tightly to me, you good and faithful women! I have learned something else in these difficult days, that you, women, are the pillars of society!

Lona: You still have not learnt anything, my brother-in-law! No, my friend, the spirit of truth and the spirit of freedom, these are the pillars of society! (Ibsen, Henrik. Doksani \& Zheji. 1990: 463-464)
\end{abstract}

Pillars of Society was considered a good play, but Ibsen did not turn on that style of drama anymore. Henceforth his realism is carried in a wider extent, and it aims to give us a careful diagram of the sequence lifeline. A Doll's House is considered as such, which sparked much debate since its inception, for the mission it gave to women in the modern society. The audience was introduced to a new concept, where the woman was an independent individual, embodied with moral functions and purposes of its own. When the play A Doll's House came out of press in 1889, the publishing house sold out fourteen thousand copies within the next five years. This phenomenon was rare and obscure even to novels, so it was hard to be imagined it could happen to contemporary plays. (Archer, W. 1893: op. Cit.18). Nora, the protagonist, at first was a victim of the male egotism, living absorbed by the nature of her father and husband. The result of Nora's weakness, which Ibsen calls the 'criminal dependence of individuality' is clearly understandable when Nora is faced with a responsible situation and the circumstances require the judgment of her morality, she does not know what to give. Nora`s full capacities emerge when she comes out from the artificial cotton wrapping of her husband, when she comes out of the sleepy joggling because of his egotism, thus rapidly developing her own energies. While author's peculiarity lies in presenting the facts of these successive changes in the scene. Nora's decision to abandon the family is the pure indicator of the highest revolt that was kneaded within her soul over the years.

An interesting way of analysing Ibsen's dramas is a closer look we should give to the philosophical invisible chain that follows the actions from one play to the other. If we consider Lady Bernick, one of the major characters in Pillars of Society, we can notice her typical dependence on Bernick, her husband; the humility she shows towards him; the devotion she makes noticable towards him and her family; thus regardless of her moral integrity at the moment when the loyalty of Mr. Bernick towards her is doubted, and many other such elements. Lady Bernick better agrees to keep silent in exchange to her social position as the wife of the Consul; accepts the silent infringe for herself in exchange to the welfare and reputation her husband can offer. Even the way she forgives her husband, seems to be somewhat hypocritical, not only because the lack of love, but also it comes at a moment when Mr. Bernick is expected to be 
forgiven by the community which surrounds him at this difficult moment for his pride and integrity. Lady Bernick is the first to step forward in order to demonstrate to others that Bernick should be forgiven the moment when he admits the fault, which is somehow contradictory with pointing his faults out the moment he is committing them. This drama is like a paranthesis to A Doll's House. ${ }^{4}$ Since the very first beginning the audience can easily grasp Nora's position, but this same audience has to wait in order to see how will things come out, which will be the tide of the events. In comparing Lady Bernick and Nora, we have to wait for the last act in both plays, in order to clearly notice the difference between these two characters, the difference between their moral dimension, the difference between what one wants and how does she achieve it.

The result of offensively boastful self-tolerance and sensual hypocrisy that welches across men's life, warns the subject of the play Ghosts. ${ }^{5}$ This too much debated play, also makes present another important issue of that time, perhaps of all times. The central idea of the play Ghosts is the distortion of individuality from the inherent weakness mainly caused by personal fulfillment. We can draw parallels to Lady Bernick and Lady Alving, not only throughout the play, but especially at the end of it. Lady Alving has the same attitude of Lady Bernick towards morality and integrity, towards the figure of her absent husband, towards the society around her. The main scope of both women is keeping the same respectable social position that their marriage to such husbands may guarantee them. Lady Bernick, as well as Lady Alving differ in total from the attitude of Nora, although the beginning acts of the three plays seem to have the same start in terms of these women behaviours.

This phenomenon of the philosophical chain lies in all Ibsen's dramas, which marks the most amazing and intriguing feature to be analyzed, following the series of works of a truly modern author.

\section{References}

Archer, W., Rosmersholm: The Lady from the Sea Hedda Gabler By Henrik Ibsen, Publisher Walter Scott, London, 1905.

Barnwell Elliott. Sarah.,Ibsen. The Sewanee Review, Vol. 15, No. 1 (Jan., 1907). Published by: The Johns Hopkins University Press

Bashkim Shehu, "H. Ibsen - Drama", Shtëpia Botuese "Naim Frashëri", 1978

Bentley, Eric.,What Has Ibsen Meant. Southwest Review 88, no. 4 (2003)

Egan, Michael. Henrik Ibsen. The Critical Heritage.London \& N. York. 1972.

Ibsen, Henrik. Drama. Henrik Ibsen. Red. J. Doksani \& Gj. Zheji. Sh. B. Naim Frashëri. Tiranë. 1990

\footnotetext{
${ }^{4} \mathrm{~A}$ Doll's House was definitely the most explosive and most criticized three acts play of Ibsen, which was performed for the first time in Copenhagen, Denmark on 21 December 1879. Nora, the main character, looks like she is living a happy marriage with Torvald and her three young children, to whom she is totally dedicated to Nora hides secret that Torvald had been quite ill and she was obliged to borrow the money needed for his recovery without her husband's knowledge. When her husband comes to discover the truth, instead of thanking her for the disponibility and enormous sacrifice shown, he causes a great strife based on jealousy. Later, Krogstad, an old friend of Mr. Helmer, Nora`s blackmailer at the same time, comes back to Helmers' and seeks not only a return to his previous job, but also in a higher position than he had. The dance, for which Nora as a character is famous for in this play, is performed in front of Helmer under a frustrated emotional state, which makes Nora jump to debut wild and violent, but beautiful, at the same time, which irritates Torvald, but he does not let others understand that. Nora, felt even more offended by his behavior, eventually admits that in their eight years of marriage he had failed to know her, and therefore she will not return to her children, until she will be able to recover her lost dignity. She decides to leave Torvald and abandons her family house with a door slam, which marks the revolt of her character.

${ }^{5}$ Ghosts is another thrilling play of Ibsen, where Ms. Helen Alving is the widow of Captain Alving, a person Who used to have a very high social reputation. Their marriage was a farce which has to hide the fact that her husband was a banal user of alcohol and also a debauched person. However this is uncomfortable marriage inherited a boy, Oswald, but, on the other hand, Mr. Alving had an illegitimate child with his servant, a girl named Regina. When the play opens, Oswald was back home on the occasion of the opening ceremony of the orphanage which would be named after his father. Due to this occasion Manders, Alving family financial officer, has also returned. Manders was also involved in an affair with Mrs. Alving, which remained unanswered on his behalf. One night before the ceremony, the house which will be inaugurated in memory of Mr. Alving, bursts into flames. This is not the only or the smallest problem Mrs. Alving had to face, because further problems stem for her from now on. Oswald confides his mother about a serious problem: he suffers from a veneral disease, syphilis, due to immoral bohemian life in Paris. This full disappointment of Mrs. Alving at this phase does not affect only her, but Regina, also, who pretends to have an affair with Oswald. The play ends with the rising sun while the last stage of Oswald's illness approaches him, while he is surrended hopelessly.
} 